\title{
Squibs and Snobs: Science in Humorous British Undergraduate Magazines Around 1830
}

\section{Citation}

Browne, Janet. 1992. Squibs and snobs: Science in humorous British undergraduate magazines around 1830. History of Science 30: 165-197.

\section{Published Version}

http://www.shpltd.co.uk

\section{Permanent link}

http://nrs.harvard.edu/urn-3:HUL.InstRepos:3372265

\section{Terms of Use}

This article was downloaded from Harvard University's DASH repository, and is made available under the terms and conditions applicable to Other Posted Material, as set forth at http:// nrs.harvard.edu/urn-3:HUL.InstRepos:dash.current.terms-of-use\#LAA

\section{Share Your Story}

The Harvard community has made this article openly available.

Please share how this access benefits you. Submit a story.

Accessibility 
Hist. Sci., xxx (1992)

\title{
SQUIBS AND SNOBS: SCIENCE IN HUMOROUS BRITISH UNDERGRADUATE MAGAZINES AROUND 1830
}

\author{
Janet Browne \\ University College, London
}

Question: Why is Mont Blanc like a plumber's shop?

Answer: Because it has a glazier in it.

(The gownsman, 5 November 1829)

Hardly anyone needs an introduction to student humour, least of all professional academics. What is not supplied by contact with fertile young minds in a contemporary university or college setting is supplemented by the memory of jokes long gone away, of skits and revues, magazines, charity weeks, of time innocently misspent in bars, and all the other extra-curricular aspects of higher education. The humour, of course, rarely lasts beyond the moment. Yet a significant part of the undertaking revolves around satirizing the current state of the institution and its teachers and in this sense is intimately tied to affairs of the day. From burlesques of local in-house politics to epigrams about the staff and curriculum, student humour reflects the ephemeral but nonetheless heartfelt opinion of those on the receiving end of education.

The learned swear

We freshmen are

Most stupid, also bearish.

It may be so,

But this I know,

Our tutor's only fair-ish. ${ }^{1}$

To dismiss this element of intellectual life as so much froth is to miss the opportunity of considering the views of the primary audience for academic learning.

Locating such an opportunity is particularly welcome in the history of science, where recent research has emphasized a need to uncover the different constituencies for science and to illuminate the opinions of the various groupings among the general public who might - or might not - engage with some of its many diverse aspects. Recent studies by Roger Cooter on the changing audiences for phrenology during the nineteenth century, by Adrian Desmond on the street-life of evolutionary theory in radical London, by Roy

0073-2753/92/3002-0165/\$2.50 (C) 1992 Science History Publications Ltd. 
Porter on patients - in distinction to doctors - and by Ann Shteir and James Secord on science for children have, with others, shown the great advantages to be gained from approaches of this kind. ${ }^{2}$ Similarly, the work of historians of medical and scientific education amply demonstrates the significance of the longlasting intellectual and social networks set up during the course of training. Researches into the interrelations between teachers and students, the relations amongst the students themselves, go right to the heart of the actual processes involved in adopting and disseminating particular scientific viewpoints through a larger social realm.

The humour of science students, however, is rarely considered. But from time immemorial these groups have cast a perceptive, often scathing, eye over what they are being offered and by whom: their comments should not be ignored. "It is not true that all Dr Russell's students fall asleep during his narcotics", as the Lapsus linguae had it in 1825.

Just as important are the jokes made about science and medicine by individuals not directly concerned with the subject yet who were members of the same intellectual body. Jibes directed at prominent teachers or university professors are likely to reflect more widespread common feelings running among ordinary undergraduates in relation to science, especially as nonscience students, then as now, were quite capable of finding the subject mysterious, maybe even boring; and were unashamed in drawing attention to the foibles of senior figures. "Methinks I see her now, personified before me", wrote a Cambridge student in 1829, paralysed by the thought of forthcoming natural philosophy exams:

her countenance and garb the vile typification of the evils she brings with her; her eyes are wild decimal points, that scarcely twinkle through the thick tresses that, composed of clustering square root signs and curling brackets, hang down her Paley cheeks; her mouth is filled with quantities raised to the $t^{\text {th }}$, which cannot escape because of her Locke-jaw.... ${ }^{3}$

To this should be added the likelihood that university courses probably included a whole spectrum of interested and less-interested parties, some of whom deliberately dropped science soon afterwards, as well as those who quite enjoyed lectures but did little more in the field, perhaps through lack of time or vocation. Though such students must have formed the backbone of the classes to whom professors lectured, year in, year out, and came to comprise a significant proportion of the wider, educated, adult audience for science, their opinions have been notoriously difficult to disclose. A close study of what such students thought can reveal a great deal about the fine texture of past scientific enterprises. Like the counter-culture of caricature, itself not unknown in the history of science, as described by Martin Rudwick in his essay on De la Beche's response to Lyell's account of the fossil record, ${ }^{4}$ humour cuts through 
to the then-important issues. Traditional student wit - written by students for students - provides access to the social world of science as experienced by an ebullient, intellectually lively, and for the most part cynical audience. Without wishing to overestimate the value of such passing resources, it does seem useful not to forget the importance of fun.

It is strange then, that so few historians of science have attended to undergraduate magazines. Despite their ephemeral nature, more copies exist in university libraries and archives than might be expected. Equally striking is how many have been published over the years: one authoritative source for Edinburgh University lists 64 titles published in that institution alone during the period from 1823 to $1923 .{ }^{5} \mathrm{~A}$ comparable source for Cambridge gives 86 for the same timespan. ${ }^{6}$ There were 78 published in Oxford from 1750 to 1901, excluding college magazines; ${ }^{7}$ and the British Library indicates 5 different titles in Glasgow University before 1830, and 8 for Dublin during the nineteenth century. Not all of these were humorous, or set out to be humorous, it should be said, and not all have been preserved: several are known only from references in other journals and a proportion of the rest often only remain in incomplete sets or single issues. The anti-Nemo, for example, a scurrilous Edinburgh magazine that "smelt strongly of the Surgeon's Square", and of which only two issues are known to be extant, was the constant butt of other student journals in the city: "a production worthy of the dunghill" sneered its rival The university squib in 1833.

Yet the earliest known publication of this sort appears to have been The student of 1750, originally an Oxford venture soon subsumed into The Oxford and Cambridge miscellany. It was followed sporadically by other short-lived publications in Oxford and Cambridge up to about 1830, when journals dealing specifically with undergraduate affairs began to follow each other in rapid succession in all the universities, taking advantage of the introduction of cheaper paper and printing processes, and also mimicking the high-brow literary periodicals similarly emerging on the intellectual scene. ${ }^{8}$ From 1835 or so, Scottish, English and Irish universities produced any number of ephemeral journals, one or two running side-by-side for a term, some with more serious intentions than others.

A full survey of undergraduate magazines would necessarily have to take into account the wide range of intellectual and literary ambitions manifested in what appears to be a great variety of publications, many of which were intended to act as a showcase and annual record of the institution as well as a vehicle for the first serious writings of its undergraduates. The St Andrews' Argus (1825), Glasgow's Academic (1826) and Collegian (1827), Aberdeen's University magazine (1836), the Oxford University magazine (1834), and the London University College magazine (1849) all fall into this latter category. The present article outlines only a few of the more obvious historical points that 
can be drawn from a handful of humorous student magazines published around $1825-35$, with special reference to two scientific skits in a Cambridge journal called The snob, and its successor, The gownsman, issued in 1829 and 1830. The sketches, which feature Adam Sedgwick and William Whewell, Cambridge professors of geology and mineralogy respectively, are reproduced towards the end of the paper.

"There is much to encourage the production of ephemeral literature at Oxford and Cambridge" wrote the editor of one Cambridge magazine, and it is easy to understand why. In amongst the timeless allusions to landladies, poor food, barmaids' bosoms, and "odes to the Rainbow tavern", there is prolific evidence that the contributors predominently wrote about the academic events or problems currently uppermost in their minds. From the medical student's soliloquy - "To pass or not to pass - that is the question (To pass? perchance rejected! - there's the rub)" - to advice that "you may put a pinch of snuff down the neck of the student who sits before you", the general tone was one of ephemeral judgement: though none the less incisive for all that. Andrew Duncan of Edinburgh was only one of many professors lampooned across the country. He "contrives to deliver the most unpopular course of lectures in the whole university" trumpeted the New lapsus linguae in 1825:

Dr Duncan's “Heads of lectures on Materia Medica".

Monday 24 January: Whey - cranberries - chemical glasses - jelly potato starch - coals - inflammation - names of different kinds of flames, as cockspur, bat's wing, \&c - process of cutting glass - process of joining glass - smoke - gas furnace. ${ }^{8}$

Indeed, most of the point was to be topical. University reform, particularly as it related to the examination system, naturally occupied a great deal of space in Cambridge journals around 1825 to 1828 , just as the Parliamentary commission investigating the organization of Scottish universities preoccupied student writers in Edinburgh from 1826. To these and other pressing political questions such as Catholic emancipation, were added countless comic references to the usual ups-and-downs of student existence - examinations, lectures, proctors and the dead hand of official authority, stagecoaches endlessly overturning, false fire-alarms, great writers that had caught the public fancy, wine-parties, escapades among the hostelries and women of the town, as well as often-expressed doubts about the possible value of education in relation to more universal problems.

Philosophers, I'm told agree

That there no vacuum can be;

But with a heart that's aching, 
As ruefully I do survey

My empty pockets day by day,

I fear they are mistaken. ${ }^{10}$

Students at Oxford in 1825 consequently read about "The first week of term" and the recollections of "Tom Trifle" in the Oxford quarterly magazine, whose grand title belied the editorial avowal in the first issue that "gusto is a much superior word to taste". The Edinburgh Anti-Nemo (1832) advised old stagers that "Liston has a large class: he might afford a new coat". The Cambridge University magazine of 1839 offered sketches on the "Characters of freshmen" with "A (very) free imitation of the first Eclogue of Virgil" and satirical critiques of the work of "Poets of England who have died young". A father, declaimed the rich young men of the Cambridge Gownsman, is a person who pays bills; and "in some cases gives lectures out of term".

The format, as might be expected, was thoroughly eclectic. Most journals imitated the new literary reviews, rather than a newspaper, say, the first such publication from Edinburgh (The Edinburgh University journal, and critical review, which began in 1823) being modelled in part on the Edinburgh review, established in 1802, and its Tory antidote Blackwood's magazine, founded 1817. Student magazines of the period therefore included items in both prose and verse, some of which were clearly meant to be regarded as parodies of an established style and others as original, and subdivided their pages into sections concerned with news and views, gothic short stories, snatches of songs or conversations purportedly overheard in a bar, "scientific intelligence", local almanacks, and irregular serials. A common trick was to headline items as "Article 1" which, like all good newspaper ploys, suggested there was more to come next time around, particularly when there was not, or to run a regular column of chit-chat mimicking Blackwood's "Noctes Ambrosianae", by Christopher North (John Wilson). Most journals included an anonymous editorial spelling out the high or low tone that was intended, especially when a new title was issued, and the texts were peppered with editorial interjections and comments. But there were few drawings or other visual material beyond ready-made woodcuts taken from the printer's dusty stock until cheap reproductions could be made: Edward Forbes's University maga of 1835 was very much the exception in the way it reproduced Forbes's scratchy sketches of Edinburgh professors (see Figures 1 and 2), although the Collegian from Glasgow managed to include four etchings before it collapsed in 1827. ${ }^{11}$ The imitative format also ran to book reviews, some real, some not. Surplus space was filled with one-liners or mock advertisements, such as the one from The snob in 1829: "Sidney Sussex College - Wanted, a few freshmen. Apply at the Butteries, where the smallest contributions will be thankfully received." 


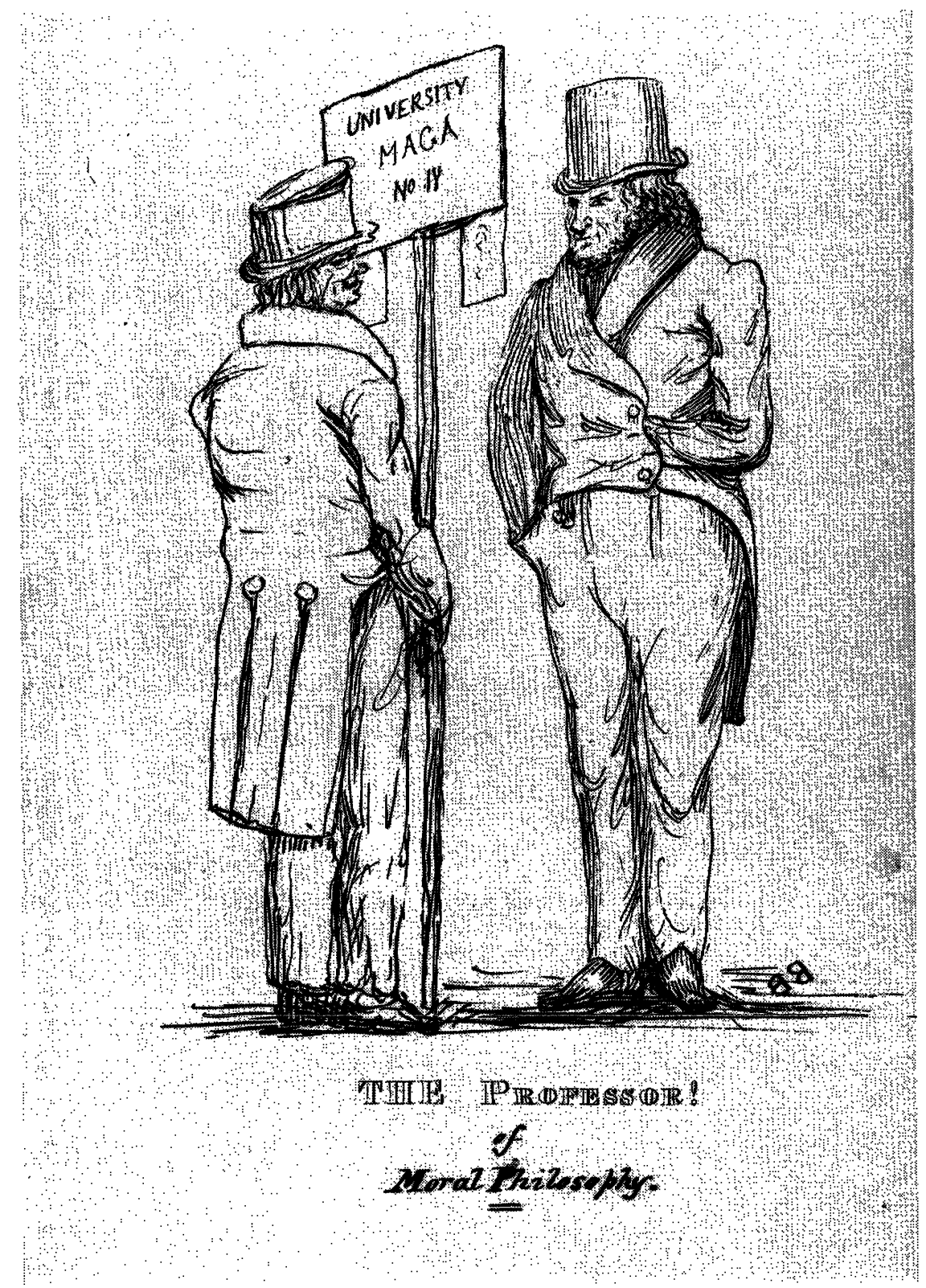

FIG. 1. "The professor" (John Wilson aka Christopher North) buying the University maga, by Edward Forbes. From the University maga (Edinburgh), 1835. Published by courtesy of the British Library.

The topicality was also primarily anonymous. Contributions were mostly unsigned or pseudonymous, a device little more than a literary conceit in Oxford, Dublin, and Cambridge, but sometimes a necessary precaution in Edinburgh where it was twice the case that the editor - and then the publisher - of an article that went too far was threatened with legal action. ${ }^{12}$ The names of the editors were similarly kept out of the paper. This convention makes it difficult to assess the likelihood of contributors ever proceeding to some 
acknowledged expertise in science or any other chosen field: several student editors are, nonetheless, known to have gone on to join literary journals after graduation, as did William Morris of the Oxford and Cambridge magazine of 1856; and at least one, the medical student Edward Forbes, became wellknown as a philosophical naturalist and palaeontologist. Yet the anonymity was not as anonymous as all that. J. T. D. Hall, for example, in his study of Edinburgh University student journals, can supply names for almost all the editors from their beginning in 1823 through to the end of the nineteenth century. Josiah Smyly gives a similar list of those pertaining to the Trinity College Dublin journal Hermathena..$^{13}$ The identity of many of the contributors must also have been known among their friends at the time, often adding materially to the joke.

Anonymity, and the cheap and cheerful nature of the magazines themselves, required that these journals were mostly advertised as available for sale at the publisher's address and it was there also that contributors were urged to send their pieces - "post-paid please". No university presses were involved, nor were any of the printers and publishers big commercial concerns.

The majority of the publishers were, in fact, so small that they go unrecorded in the standard historical guides. Presumably they depended on the proceeds from sales to cover costs on a week-by-week basis, for it is hard to imagine that student journals were anything more than a subsiduary exercise run on a break-even basis. The other works running through a local publisher's press were perhaps little better business in terms of profit: such records as there are tell a story of subsistence publishing based on a wide range of serials, usually the gothic horror stories that enjoyed a vogue during the 1820 s and which, by being published in parts, evaded the Stamp Tax, handbills, political and religious tracts, pamphlets, and any number of similar small magazines. Most of a provincial publisher's income apparently came from the retailing of newspapers. These were printed in the major cities and distributed to booksellers and stationers for sale by arrangement: in 1829 the aggregate sale of Sunday newspapers amounted to 110,000 a week. ${ }^{14}$

Print-runs and circulation figures for these university magazines are equally obscure. Perhaps only fifty or a hundred copies were printed at any one time. Certainly, it is known that reprints were issued, which suggests that the initial print-run was small. Can the Edinburgh Lapsus linguae, a slim four-page magazine issued three times a week during the academic session of 1824 , really have sold 500 copies of each number as was claimed? "An Englishman" subsequently reported that the frugal Scotsmen in his class passed a single copy around ten or twelve readers. ${ }^{15}$ The publisher of Undergraduate papers, edited by John Nichol and Algernon Swinburne in Oxford in 1858, seems altogether more judicious in his arrangement for a mere 80 copies to be

\section{Provided by the NASA Astrophysics Data System}


printed, priced at one shilling each. ${ }^{16}$ Some numbers of the The snob are extant only in what are advertised by the publisher as third and fourth editions.

The majority of these student journals were simple six- or eight-page affairs, issued each week or fortnight during termtime. Larger ones tended to be published monthly, as in the case of the London University College magazine (f. 1849), which does not otherwise fit into the humorous category, and the Dublin University magazine (f. 1833), which was both big (nearly a hundred pages a month) and gently amusing in parts. Other, more formal offerings, like the Oxford University magazine (f. 1834) and the Cambridge University magazine (f. 1839) were published termly. The print-run of these last must have touched two or three hundred.

Either way, small-scale jobbing publishers, such as W. H. Smith (no relation), a bookseller, stationer, and newsagent at Rose Crescent, Cambridge, or Talboys and Wheeler of Oxford, would have needed assurances from the eager young man with an armful of manuscripts that he was on a financially and legally solid footing. Commercial astuteness was the essential precondition of survival in the jungle of pre-Victorian publishing. Moreover, college gentlemen were not often sufficiently trustworthy with money for a selfsupporting publisher to let them hawk the resulting copies from their rooms or in the street. Cash sales, it must be assumed, were more safely handled by the publisher himself. Edward Forbes's University maga was again apparently an anomaly in the way that it was sold at the university's front gate: Forbes's drawing (see Figure 1), as printed in the magazine, shows a student (or perhaps the publisher?) with a bill-board advertising the latest issue selling a copy to a curious "Christopher North". It is also reasonable to assume that printed advertisements for incidental papers like these were too expensive for the small financial returns expected: word of mouth among the student body would have to do.

Such a hand-to-pocket existence probably explains why some publishers, on occasion, appear to have actively encouraged the foundation of yet another new journal: Mansell of Oxford reputedly asked John Nichol, then an undergraduate at Balliol, to take over a magazine which had failed after three numbers. Doing as he was requested, Nichol changed the title and got contributions from his friends in the student society "Old Mortality". Even so, Undergraduate papers only lasted for a few issues in $1858 .{ }^{17}$ The publisher never recouped his losses. Likewise, the editors of the New lapsus linguae, which folded in 1826 after a year's brief existence, went down complaining in the last number that insufficient copies had been sold to indemnify the publisher. ${ }^{18}$ The Argus of St Andrews "had to give up on account of not defraying the cost of printing". Sometimes the stress-marks began to show. In a well-documented incident relating to the University maga, the second number was issued before the first, requiring the editors to write a second (or 


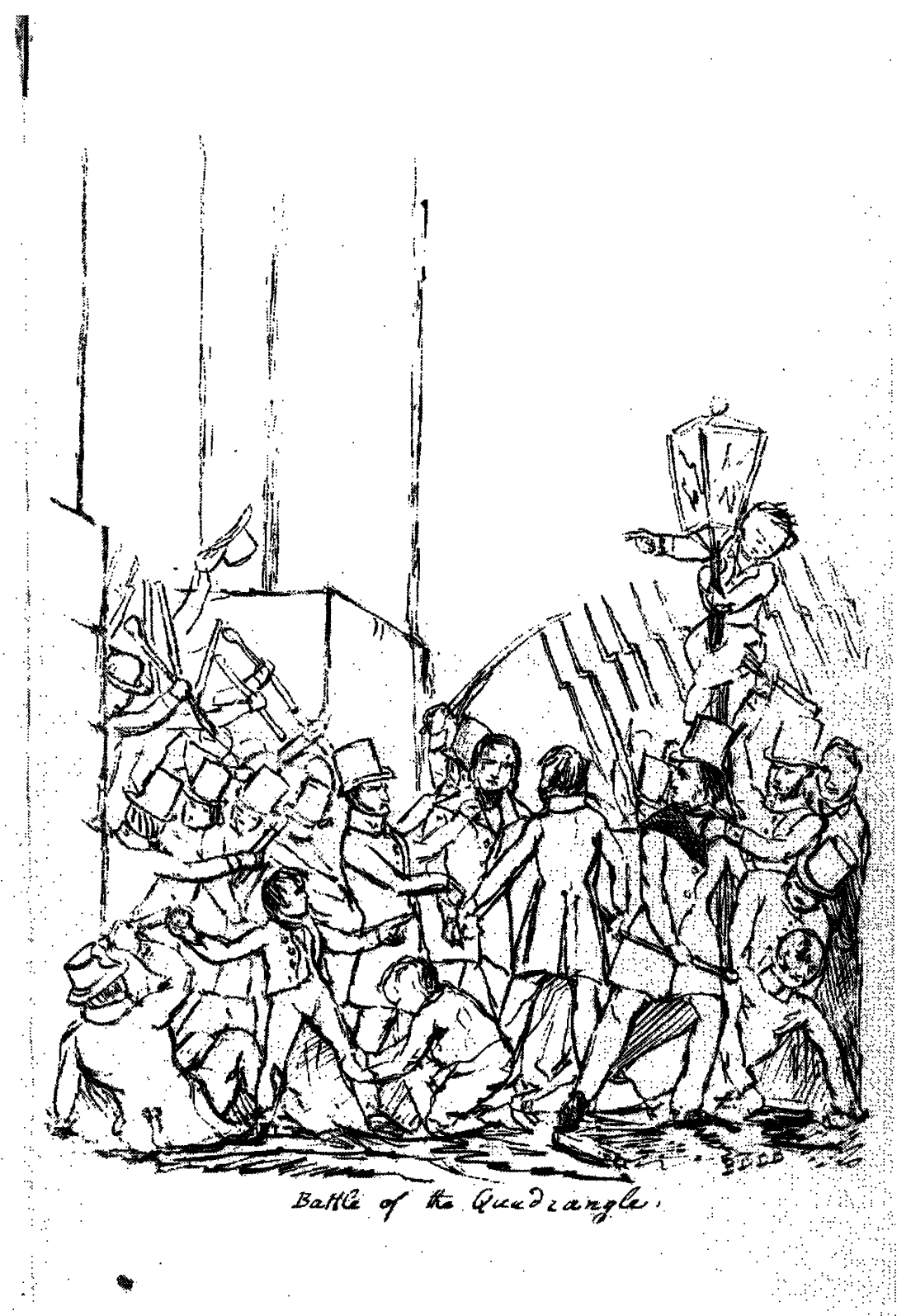

FIG. 2. "The battle of the quadrangle", or snowball riot, in which Edinburgh students fought townsmen after being attacked by snowballs in the unversity precincts. They had to be separated by the militia. By Edward Forbes. From the University maga (Edinburgh), 1838. Published by courtesy of the British Library.

first) introduction in which they hugely enjoyed the back-to-front situation for which they entirely blamed the publisher.

As for distribution, it is rare to find small humorous magazines offered for sale anywhere other than their home-town. Larger, more serious journals were apparently available in other cities, presumably through pre-arranged relationships between publishers: the Oxford quarterly magazine was published in 
both Oxford and London, for instance, and it seems to be the case that most of the Oxford and Cambridge journals were available in their sister cities, some also being advertised as further published in Glasgow or Dublin. Such a pattern would seemingly go with a larger print-run, fewer issues, and altogether more self-consciously intellectual intentions.

Science in these self-confessed humorous periodicals went beyond puns and jokes about professors into areas of more general intellectual, political, or social concern. In 1824 Lapsus linguae took a pronounced stand on the threatened closure of the Edinburgh University Natural History Museum to the public. ${ }^{18}$ As was common, the question was made funny by including sex. "Philogunaikos" complained that restricted access would mean no further ogling of the women visitors:

Talk not to me of the musty old pages

That have slumbered in dust for a dozen of ages;

Rave not to me of your vile mathematics;

Let Hope with his sulphur, his gas, and caloric, -

Let Wilson with sentences so metaphoric, -

Let Dunbar with his huge "Collectanea Majora", -

Let Pillans, and Ritchie, and Brown, sine more, -

All shut up their class-rooms, - 'tis nothing to me,

I have taken their ticket, and payed them their fee!

But do not, O! do not shut up the Museum -

The fairest of buildings, - the Scottish Lyceum;

And do not, O! do not shut from our College

The loveliest sources of beauty and knowledge...${ }^{20}$

Comments in the same vein were raised when John Leslie, professor of natural philosophy at Edinburgh, gave popular lectures on science to a mixed audience during the winter of 1826-27.21 The Cheilead, or university coterie took a sportive line on the corpulent, ageing, bachelor don:

Professor Leslie opens a class after the holidays, for the purpose of instructing ladies in natural philosophy .... 'Tis probable the Professor is determined at length on "taking unto him a wife" and of course the best way to chose is to have a great many to pick from. The Professor intends showing the Ursa Major personally through his long glass, with the use of the globes, how to raise a perpendicular incubation by means of featherbeds - the laws of gravitation - the sun's disc - and the signs of the zodiac as the ram, bull and lion. These and many other curiosities as the little bodies (or as some say animalcules) in various liquids in the human body, as in the blood, and its secretions, forming altogether the most popular course ever delivered in the university. ${ }^{22}$ 
When Leslie's class opened in February, the same magazine suggested "he was up all night practising before a full length mirror - for attitude and effect".

Medicine, as might be expected in Edinburgh and Glasgow, received its fair share of criticism, ranging from classification schemes of medical "bores" in Janus (1826) that included deft references to Robert Jameson, professor of natural history, as a fossilized bore "said to be preserved in some cabinet in Germany", to remarks on "medical puffing" aimed at John Lizars, proprietor of an extra-curricular anatomical school. Phrenology, too, was well represented in Scottish student literature, adding another layer to the wide range of ephemera discussed by Roger Cooter. ${ }^{23}$ The University medical and quizzical journal published in Edinburgh in 1834 even ran to a phrenological discussion of cheese mites - among whom it was insisted there were many talented individuals. ${ }^{24}$ And Glasgow's Academic lived long enough to print a song of the phrenologists that began:

What teaches that the human mind

Tho' half before and half behind

Is yet within the head confined -

Phrenology!25

Grave-robbing featured during the later 1820s ("These men are always turning up something new ... "), as did items about Robert Knox, the most notable extra-curricular teacher of anatomy in Edinburgh who was widely believed to be receiving resurrected corpses. ${ }^{26}$ Long before the Burke and Hare scandal broke in 1828, an affair which did directly implicate Knox, the anatomist was being associated with criminal activities by undergraduates and accused of what Richardson calls "professional silence". To The Cheilead in January 1827, Knox was the foremost member of the "Kingdom of Utopia", an anatomist engaged by a "society of learned men" to teach the way of "cutting up our fellow creatures":

How shocking at this civilized time of day

To run away with dead men - friend or foe

And cut a leg, and then an arm away

And pay five guineas as the markets go -

To me it seems most shocking - and the rather

As sometimes we must cut up our own father. ${ }^{27}$

Henry Warburton's Anatomy Act was further discussed by The university maga when Edward Forbes was editor.

Looking at student magazines can therefore provide information about what the rumours were or bulk out local scientific-cum-social controversies, although there is no need to go as far as Charles Whibley in asserting that 
"scarcely a single great movement has taken place without suggesting a jocular ballad to an undergraduate". ${ }^{28}$ Magazines can also on occasion indicate changes in scientific or medical practice of greater or lesser significance. An article in the New lapsus linguae (a reincarnation of the former title that ran for the academic session of 1825-26) by "Philo-Laennec", entitled "Memoranda of a stethoscopian", suggests that Edinburgh students were in 1827 well accustomed to using the stethoscope. ${ }^{29}$ The two squibs reprinted below from the Cambridge Snob further show that experiments, specimens, and practical demonstrations were commonly employed in natural philosophy lectures at that university. Though such anecdotal evidence mostly serves to confirm what is already known about the teaching of science, it does, nevertheless, fill out the established historical picture and reveals the full extent of, say, familiarity with a new instrument, or a general but rarely expressed assumption among the students about specific scientific experiences.

One particular Cambridge magazine reflects these points directly, although others might as easily have been taken as an example. The snob, which called itself a "a Literary and Scientific journal NOT conducted by the Members of the University" was a weekly magazine of six or eight coloured pages issued for less than three months (eleven numbers) in the spring of 1829. It took the place of a short-lived Cambridge magazine and was rapidly succeeded by The gownsman: A literary and scientific journal now conducted by members of the University, an equally ephemeral publication that lasted for 17 issues between November 1829 and the summer term of 1830. The word "snob" here represented university slang for a townsman, as explained by an opening remark from the editor who "thought he would try whether the genius of the town did not equal that of the university". Contributions were accordingly phrased as if from local tradespeople. In The gownsman the heavy-handed pretence was dropped. The snob and The gownsman were intimately linked by having the same editor, publisher and contributors, and should be seen as one journal with two titles: titles that clearly fed off each other.

It is usually assumed that The snob was edited by William Garrow Lettsom of Jesus College and indeed Lettsom had a definite hand in the magazine..$^{30}$ Grandson of the Quaker physician John Coakley Lettsom, who was renowned, if nothing else, for the doggerel verse about his medical manner ("If after that they chose to die,/What's that to me, I. Lettsom"), this young man was an enthusiastic mineralogist and amateur natural historian. After taking a good honours degree from Jesus, he went into the British diplomatic service, ending up as chargé d'affaires in Uruguay, during which time he published with Robert Philips Greg a Manual of the mineralogy of Great Britain and Ireland (1858), still a standard work of reference for British minerals. Lettsom, who evidently attended both Whewell's and Sedgwick's courses, was 
probably responsible for many of the notes and articles on science in The snob and Gownsman.

Brief parodies of the sections labelled "Scientific Intelligence" found in more serious natural history journals of the time are thus attributable to him. Under the heading "Entomology", for example, the magazine announced:

A fine specimen of the great parish blue beadle was seen last Sunday at $\mathrm{St}$ Pancras. Lace - gold, hat cocked: in all other respects corresponding to the common Scarabaeus tonans which is generally met with at public vestries, country church-yards, \&c.

The allusion to the university's Esquire Bedell arriving in London dressed for business (the St Pancras area was where Cambridge coaches began and terminated) would not have been lost on readers even after the pun on beetles had had its day. The Bedell - William Hopkins, the great mathematical tutor of the university, later influential in theoretical physical geology - was in London to drum up liberal opposition to a reactionary university grace, for as soon as it became known that the Duke of Wellington intended to introduce a bill for the relief of Roman Catholics - passed in Parliament later in 1829 conservative elements high in the university system resolved to petition Parliament against it. ${ }^{31}$ Hopkins did his work for the liberal cause well. As the Cambridge chronicle naïvely recorded, the resolution was rejected by "the somewhat unexpected arrival of several members of the Inns of Court, who came down for the express purpose of voting on the occasion". Though entomology served as little more than a vivid metaphor here, the interweavings of what was then a popular undergraduate hobby and the larger satiric concerns of politics are suggestive of the prominent role that natural history took in university life.

Chemistry, too, came under the same critical eye. The subject (at that time taught by James Cumming, a man singled out in most other contemporary sources as a remarkably good lecturer) brought forth only morbid reflections on the examination system. His classes were "a strong opiate" comprising, in various proportions, "1 Sermon, 1 Act, 2 Opponencies, 1 Clerum, 1 Determination". Geology was not neglected either in a series of dreadful puns along the lines of: "Why is Tompkins, my body servant, when not on foot like the vale of Chamouni - Because he is a valley."

The snob's chief projector was William Williams of Corpus Christi, a clever eccentric who faded into literary obscurity after leaving Cambridge. He took his B.A. degree in 1829, staying on at Corpus to take Holy Orders. In 1831 he became curate of a parish in Hampshire and then, from 1833 till his death, was vicar of St Bartholomew's, Winchester. But for The snob he would never be considered of historical interest: precisely the kind of invisible figure whose views about science are otherwise so difficult to determine. 

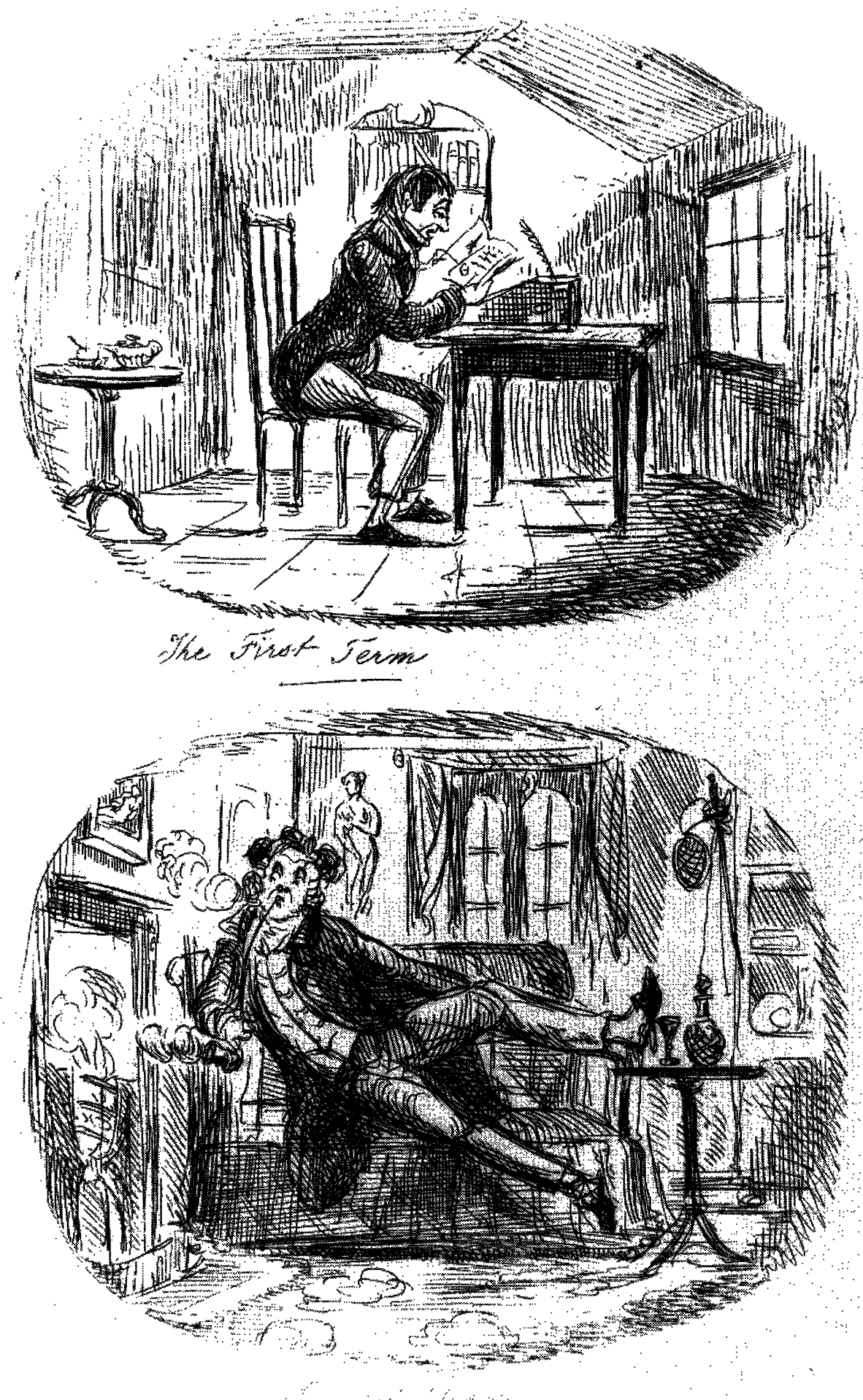

FIG. 3. "The first term" and "Second term", by William Makepeace Thackeray, circa 1829. From Etchings by the late W. M. Thackeray while at Cambridge illustrative of university life (London, 1878). Published by courtesy of Cambridge University Library. 
In March 1829, Williams was joined on the magazine by William Makepeace Thackeray, an undergraduate at Trinity. For the next six months Thackeray threw himself into writing anonymous comic pieces for publication, becoming a close friend of Williams's in the process. Some authorities credit Thackeray with being editor, if not of The snob at least of The gownsman. Research shows otherwise. ${ }^{32}$ Like many such youthful endeavours, these first literary steps always retained a special place in Thackeray's heart: he eventually went on to reconstruct the idea of a "snob", reversing the expression from its original meaning of a Cambridge townsman to the one more familiar that signifies a person who "admires mean things". Thackeray's "Snob papers" in Punch during 1846 and 1847, and his later collected work, the Book of snobs (1869), while not directly elaborating on items once written for the magazine, include sketches of university snobs (in the modern sense) that owe a great deal to his experiences with Williams and Lettsom at Cambridge. Thackeray in fact wished to dedicate the Book of snobs to Lettsom.

Through Williams, Thackeray came into contact with an extraordinary circle of literary friends whose work, with his own, in time created much of the characteristic tenor of the later Victorian period. Intimate with Edward Fitzgerald, Richard Monckton Milnes, John Allen (later an archdeacon and model for Dobbin in Vanity fair), Henry Matthew (a profligate, glamorous individual, already sent down from Oxford, who had only survived a year at Trinity and was now pretending to study at Sidney Sussex), and James Spedding, Thackeray happily gambled and drank his way round the colleges while exploring and discussing his own tastes in English literature. Impromptu "before-and-after" sketches of a university freshman made at the time for a private album (see Figure 3) speak directly to himself, if not for this host of clubbable friends. The three Tennyson brothers were other contemporaries at Trinity, as Charles Darwin was at Christ's, but Thackeray seems not to have known any of them well, even though they shared several mutual friends among the Apostles and elsewhere.

He also experienced at first hand general supervision in mathematics from William Whewell, the college tutor (though being taught privately, as was the custom, by Henry Edward Fawcett and 'crammed' during the holidays by his friend Williams), and may have attended some of Whewell's professorial lectures in mineralogy: certainly he relayed jokes to his mother about "Mr. UL". Whewell and his tutorial vocation of mathematics - a subject which Thackeray sincerely hated - were later worked into a thinly veiled caricature for Punch of a professor of fisticuffs. ${ }^{33}$ "I should like to know in some instances whether all your Algibry and Mathemadix, your Greik and Latn and that, would serve a young gent half so well as a good nollidge of sparring and fibbing" - clear reference both to Whewell's argumentative nature and to the 
Cambridge legend that a prize-fighter had once exclaimed "What a man was lost when they made you a parson!".

Thackeray made his debut into print in The snob in April 1829 with a mock Prize Poem, a form of competition taken very seriously in the university proper, on the subject chosen for the year: Timbuctoo. The prize itself was won by Alfred Tennyson for an adaptation of some verses he had in hand on the battle of Armageddon. Thackeray's version, phrased in spanking rhyming couplets, was suitably dressed up for the occasion with learned footnotes, some of them in Greek, which he thought appropriate for a work that included lines like "Pop goes the musketoons".

It was a great success. "Timbuctoo received much Laud" he told his mother; "how eagerly did I suck it in!" The editor noted that The snob would be glad to hear again from " $T$ ", and Thackeray was quick to act on the hint, sending in some tortured effusions in the mangled English that he came to perfect in the Yellowplush papers and elsewhere. Within a week or two he was a major contributor, sitting up late at night for the rest of term with Williams, composing the weekly issue assisted by plenty of claret and cigars:

I fell off my stool laughing at my own wit when I sat with the other editor composing the material - oh how we shrieked and clutched each other and could hardly see for tears of mirth. It is hard to say which pleased us most - our attempts at satire or the straightforward slapstick. We sold it for $2 \frac{1}{2} \mathrm{~d}$ a copy and prided ourselves on value for money. It was packed with solemn thoughts such as "Asparagus and poetry are equally worthless when forced", and little ditties that mocked the current style like "Ode to a Casting Net"

By the pond's pellucid stream

My casting net

Will soon be wet

Beneath the moon's pale beam

Well I didn't write it but I still think it is funny even if you are already half way across the room throwing the paper out of the window in exasperation. Nor did I have a hand in our serial "Moll of Wapping" which made me laugh most of all, or "An Essay on the Great Toe, together with the Nature and Properties of Toes in General" in which the delivery of a certain famous man was mimicked. No, my claim to fame was a poem called "Timbuctoo", which may or may not have been a satire on Daddy Wordsworth, complete with notes for your edification. ${ }^{34}$

As well as the article on the "Great Toe" mentioned above, which was little more than a facetious dig at John Leslie and his lawsuit against Blackwood's magazine, ${ }^{35}$ The snob and Gownsman carried two lampoons on scientific 
lectures by Sedgwick and Whewell: the one on Sedgwick appeared in the sixth number of The snob, 14 May 1829; that on Whewell in the third number of The gownsman, 19 November 1829.

Attribution of authorship for these is not fully possible, although it is most likely that all three of the main contributors were involved. Lettsom undoubtedly attended the courses delivered by Sedgwick and Whewell. Yet existing records seem to indicate that the other two were equally concerned, perhaps also attending the courses. The air of a verbatim account suggests that all the authors were more than familiar with both of the professors' lecturing styles. Certainly, the piece on Whewell was run over the signature " $\varepsilon$ ", a cognomen that features regularly in the magazine and is attributed to Thackeray by Williams's son in a brief note of $1884 .{ }^{36}$ The repetition of the "Mr. UL" in Thackeray's letters and "Professor F. Uel" adds weight to the assertion. Gordon N. Ray, however, in his most recent study of Thackeray, believes this was a mistake of memory and that Williams, on the contrary, used the " $\varepsilon$ " whereas Thackeray opted for " $\theta$ ". The use of " $\varepsilon$ " for the editor and of " $\theta$ " for Thackeray seems a fairly unremarkable assumption. ${ }^{37}$ Williams, moreover, was a personal friend of Sedgwick's, as evidenced by one of Thackeray's letters from Paris in 1829; it is probable that Thackeray got to know Sedgwick during the same Continental trip. ${ }^{38}$

Notwithstanding the problem of attribution, these two short squibs can tell us much about the impressions of science running in undergraduate minds during 1829 . Sedgwick, naturally enough, was associated with an earthy form of practical stratigraphy; Whewell with high-flown romantic laws and forces of nature:

Snob Lectures, No. 1.

Lecture on Cookery, by Professor S. Wick, C.C.C. ${ }^{39}$

In my last lecture, gentlemen, I attempted to point out to you, as clearly as possible, the peculiar formation of the common dumpling, confining myself chiefly to the cases where the internal conformation is found to consist of apple; I will not detain your attention much longer upon this very interesting part of cookery, but leaving you at your leisure to pursue the subject with greater minuteness, and strongly recommending to your notice Mrs. Glass's excellent work, and also Dr. Kitchener's more elaborate performance, I shall content myself with just mentioning one or two singular varieties, or, I may rather say, digressions from the beautiful law generally observable in the stratification of the dumpling, and then go on to a more difficult, though, at the same time, one of the most interesting portions of the science.

But, stay a moment, I may as well just mention one thing sometimes met with in apple-dumplings, which I forgot to state in my last lecture. It is 
sometimes found upon taking the dumpling out of the pot, that in the crust, or covering, or coat, there has taken place a rupture, generally in a vertical direction, that is, I do not mean to say that it is not sometimes horizontal, for there is no reason at all that it should not be so, that is, as far as I know; for I will not assert that the horizontal rupture ever does take place, yet I do not deny that it can; but whatever may be the real state of the case, all the ruptures that I have seen are in a vertical direction, such as - let me see - I ought to have one here, one that I consider an excellent specimen, inasmuch as the serrated edge is plainly visible without the aid of the microscope; - ah! here it is. Now observe, gentlemen, this dumpling prior to boiling, of which by the way I was an eye-witness, it having taken place in the Town-hall kitchen, the cook of which perhaps it may be as well to mention is an intimate friend of my own, one whom I esteem as an amiable and a worthy man, but who, I beg leave to say, strangely errs in his treatment of the dumpling. But, as I was about to say, gentlemen, this dumpling, prior to boiling, had a skin as unruffled as any lady's; only look at the appearance it now presents (much laughter). On one side no material alteration has taken place; but on the other the configuration is totally disordered; the apple, which was before the lowest of the strata, has here become visible; it seem as if it had been displaced by some mighty internal convulsion, and had been pushed, - shoved, thrust up, as it were, between these two edges of paste.

Now, how are we to account for this? M. Freynel, in his little elegant, though rather theoretical treatise, accounts for it in this manner. $\mathrm{He}$ reasons from analogy, that since the dumpling bears a figure somewhat similar to that of the earth, that is, of a sphere flattened at opposite sides like an orange, it follows of course, that since the poles of the earth are possessed of a magnetic attraction, as is well known, the poles of the dumpling also must possess the same property, and that therefore these poles acting attractively on the equatorial particles of the dumpling, and thereby pulling asunder - tearing - rending the outside coat, causes the above-mentioned disruption.

This is certainly an ingenious method of accounting for this singular circumstance, but there is still one fundamental error - it refers a particular result to a cause which would evidently produce a result directly opposite to the former. For the polar attraction of the dumpling would manifestly cause a horizontal hiatus, while this specimen, and in fact, all those I have seen, have the opening vertically placed. How then is this to be accounted for? But I will not detain you longer upon wild and extravagant theories, but give you at once my own solution of the question, which I consider as at the same time giving an adequate cause to this extraordinary result, and also being perfectly consistent with common 
sense, or our own observation. If we consider then, gentlemen, that, - but I hear the clock striking, and therefore I will not detain you now, but reserve this subject for my next lecture.

\section{Lecture on Charcoal \\ By Professor F. Uel. ${ }^{40}$}

I come now, gentlemen, to the third class of fire agents in internal domestic economy, I mean charcoal; and let me here remark, that although I have placed the substance in the third class contrary to the position and doctrine of Phillips and his party, yet it is not because I disagree with that eminent man with regard to the superiority of charcoal over wood, (which you may observe forms the second class in my list) in making a fire for the general, as well as the more particular and delicate purposes of cookery; but inasmuch as wood is the primitive substance, and charcoal a combination of wood and fire, and therefore, a pyrites (for I deny that the word pyrites arises from the substance emitting sparks when struck) I have, on that account, following a synthetical order, begun from the simplest.

Let us, then, first consider charcoal with regard to its physical characters. The external forms that it assumes are exceedingly various; nature seems to have forgotten her ancient feuds with the deity of fire, and having persuaded him to co-operate with her in the work of creation, to have celebrated their union by the richness, the variety, and the fanciful indecision of her productions in this class. But the most general form met with is a cylinder, sometimes straight, but then of no great length; or, which is oftener the case, bent and twisted into a variety of shapes. The law of its formation seems to be this; and here, let me beg you to remark, by what a simple method, and in how self-evident a manner the law of formation may be traced, when it depends upon the combination of an invisible, imponderable nature with any matter of opposite character. The primitive substance from which it is formed being wood, indiscriminately chosen, which must consequently be of variously contorted cylindrical shapes, it follows therefore that the lumps of charcoal should be of the same shape, since the combination of fire with the wood can evidently cause no alteration in their structure. How exquisitely beautiful is this! Nature, with the simplest law to regulate her movements, viz. the nonalteration of the material attributes of the component in any combination of substances, by the infusion of the immaterial attributes of the other; thus, since the principle of fire is invisible, and therefore when combined with wood must still bear with it the attribute of invisibility, yet the resulting compound charcoal is still visible, and possesses all the material attributes of shape, size, \&c. that wood originally possessed: I say Nature,

\section{Provided by the NASA Astrophysics Data System}


with this simple ruling law, has so incessantly amused herself in perishable charcoal, that her productions appear rather to be the thousand changes of some rich and fantastical firework, than the effects of a determined creating principle. For Nature having once amused herself in the creation of twigs and branches, which in every tree are so various in form and size, crossing and interlacing one another in such an infinite complexity of direction, that we are led to imagine that some raging nest of rearing and hissing snakes have, in the midst of the maddest frenzy, been looked upon by the Medusa eyes of nature, and conscious of their own noxiousness shudderingly chilled into wood; but I say, nature having once amused herself in the creation of these, without the trouble of a new creation, has by combination amused herself a second time as extensively as before.

My time, I am afraid, is nearly expired; but before I close, I must endeavour by a simple instrument that I have here, to explain to you, what I consider to be the law of formation of the primitive substance - twigs and branches. It may be by some condemned as theoretical, but since it leads to such beautiful results I must be excused for still insisting upon it. This, then, that I hold in my hand, gentlemen, is the wire of a ginger-beerbottle, twisted, by the part it has played in the preservation of the beer, into a most irregular form. I have here also a button-mould, extracted from a button in the back of an old black coat, which some, perhaps, of my auditors may have seen. I wore it at the Commencement, 1828. Well, through the hole in the centre of this button I insert the wire, and then holding one end of the wire in the left hand, with the fore-finger of my right - no, no, with the middle - no, yes - that is no - any how, with one of the fingers of my right I give the button a rotatory motion, letting it at the same time slide along the wire. Now it is evident its circumference will trace out in space an irregular cylindrical shape, and by varying the contortion of the wire, we may form as many cylinders of different irregularities as there are branches and twigs in all the trees that have ever existed; and it is in this manner I conceive that the law of formation is regulated; the creating or spiritual principle of nature assumes the form of an ideal circle with a hole through the middle, while the existing or material principle assumes that of a contorted mathematical line; and thus the former, revolving in its own plane, which perpendicular to the latter moves uniformly along it, fashions, begets and creates twigs and branches.

In 1829, when the first squib was written, Sedgwick was in his prime as a geologist. Woodwardian professor of geology since 1818, he had succeeded in promoting his subject so effectively through annual courses to undergraduates that he was one of the most popular and esteemed lecturers of the university. Good-humoured, jovial, and eloquent, his professorial reputation was secure. 
His position among British and continental geologists was similarly assured. For the three or four years beforehand he had been working on the stratigraphy of the transitional rocks of Yorkshire and Scotland, particularly the difficult beds of the new and old red sandstones and the magnesian limestone, and was much admired in the natural philosophical community for his success in untangling local details to create larger interpretations of regional structure. In a move reflecting some of this growing approbation, he was appointed president of the Geological Society in February 1829. Yet the article in The snob was written some fourteen months before he first set out with Roderick Impey Murchison to investigate the older rocks of Wales: it therefore provides a chance to 'see' Sedgwick before what is customarily considered his life's work on the Cambrian system swept into view. ${ }^{41}$ Significantly, the paper was written just at the time that Sedgwick abandoned any residual belief he may have held in Wernerian theory - the water-based explanation for the origin of primitive rocks - in favour of igneous forces. "For a long while I was troubled with water on the brain", he wrote in his memoirs; "but light and heat have completely dissipated it". ${ }^{42}$

The focus of Sedgwick's work in this period was to judge from the presence or absence of "unconformities" the relative ages and periods of deposition of the different rocks and whether lower beds had been displaced or forced through others by the action of a presumed internal heat of the earth. The character and origin of dykes, where an enormous mass of strata had been "rent asunder" and filled in by some other rock, was crucial here: Sedgwick, like most igneous geologists of the period, believed such phenomena to be heat-related in origin, and probably formed by intrusions of molten rock from below. The sketch in The snob cleverly draws on these contemporary concerns through its use of the idea of a split in the pastry coat of the dumpling - a vertical split, not horizontal, as the cod professor insisted. The cooked apple, too, represented the hot, internal core of the earth as believed to exist by Sedgwick and others.

Whewell was just as notable in thrusting young university and metropolitan scientific circles. In 1829 he had been professor of mineralogy for a year - a moment in his early career often eclipsed by the weight and variety of his later interests. Even the most recent assessment of Whewell's many achievements barely touches on his brush with mineralogy during the 1820s, as also Rachel Laudan's survey of the important role that mineralogy held in the history of geology neglects to evaluate his work. ${ }^{43}$.

The immediate background to The gownsman's sketch was the publication of Whewell's essay on the classification of minerals in $1828,{ }^{44}$ in which he gave his own idiosyncratic - though influential - method of analysis and arrangement. Having been greatly impressed by Friedrich Mohs's work on minerals that involved classification by comparative hardness and external 
symmetry, Whewell devised a mathematical scheme based on the idea that the ultimate structure of crystals was an arrangement of invisible rhomboids making up various kinds of lattice-work from which the external regularities of the mineral could be calculated. Each "class" of minerals was considered by him as the different external manifestation of a single, unitary cause whose laws of action could be captured in mathematical form.

First advanced in the Philosophical transactions of the Royal Society in 1825,45 Whewell elaborated this scheme to incorporate Mohs's results in the textbook for his students. As The gownsman makes clear, Whewell saw the work as setting out an entirely new mathematical crystallography that replaced William Phillips's standard Elementary introduction to mineralogy (3rd edn, 1823). Phillips, until then the acknowledged authority on minerals, had based his system on the popular notion of measuring the angles of the planes of crystals with a goniometer - in practice favouring instruments and external form over mathematics and internal structure. To Whewell, so deeply involved with furthering the introduction of modern Continental analysis to the university curriculum and British mathematics in general, so much in favour of using high-level calculations in his other specialities of architecture, dynamics and mechanics, and so predisposed to invoke romantic, abstract laws of nature, in which natural phenomena were understood as transient physical representations of some other fundamental principle, Phillips's system was simply out of hand. Interestingly enough, the system of mineral classification later put forward by William Lettsom, one of the probable authors of the squib, neatly combined Whewell's and Phillips's work. The sketch moreover touches on Whewell's weakness for coining new names and pulling together very diverse phenomena, propensities which were first indulged in his mineral textbook.

More telling, perhaps, from the social history point of view is the way these student sketches offer information about the personal style of the lecturers and the implications they hold as to the responses of their imaginary audiences. The article relating to Sedgwick, for example, indicates that his famed rhetorical power was less obvious to undergraduates than to the journalists and older men who reported on his public lectures. The repetition of words with the same meaning, like a recitation from Roget's Thesaurus; the crescendo to a final explanation only to be stopped by the clock, a classic comic device that Sedgwick surely never used but which in the hands of these writers suggests an inability to get to the point; the circuitous route taken through a survey of possible causes and alternative theories; and the faint praise bestowed on other scholars without a proper rehearsal of their views; all of these point to an over-earnest, loquacious style that sometimes failed to tell the student anything relevant.

Such an implication runs counter to most of what is known about 
Sedgwick's lectures. His public performances, as related in contemporary sources, were said to be magnificent, typified by the end-of-term geological excursions on which he took his class. Some fifty undergraduates, plus a further twenty or so visiting enthusiasts, would go out into the countryside on horseback to listen to extempore lectures about the structure of the earth: standing on the edge of a lime-pit at Cherry Hinton or on a gravel bed in Barnwell, Sedgwick invoked the grandeur of the changes that had taken place and conducted his audience of "academic horsemen" back through time to imagine an earlier state of things. The Cambridge chronicle, 10 April 1835, described one such equestrian event that ended with the students leaning out from the octagonal lantern of Ely cathedral to survey the alluvial plains. Similarly, Sedgwick's out-of-doors performance during the British Association meeting of 1838 in Newcastle drew admiring gasps from senior figures present. According to John Herschel, Sedgwick - who jumped up onto a small spit of rock on the beach at Tynemouth - led an audience of three to four thousand colliers, the "rabble" of the area, from a consideration of the "scene around them to the wonders of the coal-country below them, thence to the economy of a coal-field, then to their relations to the coal-owners and capitalists, then to the great principles of morality and happiness, and last to their relation to God, and their own future prospects". ${ }^{46}$ Despite the "sublimity" of the occasion for some of the listeners, it seems possible that the miners actually felt something akin to restless undergraduates. The snob may provide a closer view of the opinions of Sedgwick's intended recipients. Pompous obfuscation from Whewell in the second article suggests that he too was at times meaningless to a particular section of his audience.

The two sketches also reveal the emphasis in Cambridge on practical demonstration - the dumpling and the button are both exhibited in class to support the lecturer's words, accompanied by a discussion about their origins (Sedgwick was an "eye-witness" of the boiling) and manipulation by the lecturer to illuminate his point (Whewell's coat button twirling down the wire). The pleasure in Whewell's fictitious demonstration is that it explains nothing - the exhibition bears no direct relation to the questions he addresses. He might just as well have stood on his head for all that the students understood what he was driving at.

Less obvious, but worth remarking, is that the skits unintentionally reveal the extent to which these two professors based their spoken lectures on their own continuing work in the subject. Printed syllabuses and textbooks can only go so far in indicating the topics meant to be discussed and no way at all towards what the audience may have heard, or thought they heard. ${ }^{47}$ Discrepancies like these are very obvious in comparing Robert Jameson's natural history syllabus for Edinburgh University with the surviving sets of student notes taken during his lectures. ${ }^{48}$ Nor are the later memoirs and recollections 
of students fully reliable sources about the content or style of lectures: in some instances, as a study of Charles Darwin's time at Cambridge demonstrates, the main protagonist can say one thing ("I did not even attend Sedgwick's eloquent and interesting lectures") when a friend can say another (Darwin "regularly attended"). ${ }^{49}$ But in these contemporary fictional accounts, however funny they were hoped to be, geology and mineralogy students were given up-to-date information about topics close to the teacher's heart. Sedgwick's work on stratification and Whewell's classification of minerals were taught fresh from the practitioners' personal researches. Or at least, that was the impression the student satirists received.

This state of affairs is not often reiterated in lampoons emanating from Edinburgh University. Although Edinburgh lecturers must have mentioned their own work and surveyed recent studies in the field, and several of the medical professors, such as Thomas Hope, were noted for their practical demonstrations in the natural sciences, satirical sketches published there primarily focused on the inflamed controversies running riot among the professors or on arguments between the academic body and the outside world. James Hamilton's row with the university Senatus about the academic status of midwifery loomed large in the Lapsus linguae. "Professor Hamilton", wrote "Criticus" in 1825, "is considerably passed the meridian of life":

Naturally averse to the more laborious and arduous studies of his profession, he seems entirely to have neglected the very important and fundamental branches of Anatomy and Pathology.... Gradually, as it became the custom for young men to think for themselves, they began to discover, that though the Professor retained his opinions unchanged, this was by no means the case with the rest of the medical world; and, on trying their doctrines by the infallible test of experience, it was found that Dr. Hamilton was wrong.... Yet this is the man in whose favour the TownCouncil have come forward in martial array. ${ }^{50}$

All the Anti-Nemo had to say about Hope's chemical displays was that: "Sulphuretted hydrogen and his janitor taught chemistry in the university: the former was a man remarkable for pride, covetousness, shocking bad legs, and two old coach horses; the latter was the prototype - a kind of duplicate - of his master." 51 And the University maga, admittedly attacked by its rivals as a "sort of castrated medical magazine", had harsh thoughts on Alexander Monro, the third and dreariest professor of anatomy:

O Personage of personages!

Thou scion of illustrious sages!

Name glorious through three distinct ages!

Though very differently glorious - 
Famous through two, - but now notorious:

The grades are three - the fame was one;

Made by the sire, used by the son;

Till sinking with each generation,

It now demands a new creation.

The first, the glorious of the three,

The founder of the $\mathrm{M}-\mathrm{os}, \mathrm{He}$ !

Who not content to be himself resplendent,

Made and left fame enough for each descendant;

The second got it - used it too,

But still he added something new;

He gave his lectures to the third,

This one can read them every word;

And though he reads them mighty ill,

Yet manages the place to fill

Which $\mathrm{M} \longrightarrow$ os long have fill'd — and longer will....

Thus an eternal $\mathbf{M}-\mathrm{o}$ lives,

And thus eternal lectures gives! ${ }^{52}$

Again, there is little emphasis in Edinburgh squibs on the role that instrumentation or demonstration might have taken in lectures. Only one magazine in the period considered here carried an account of physical experiments - in Professor Leslie's class - and that was delivered in order to ridicule. They were, furthermore, performed by a non-too-handy assistant:

The third objection is no less serious than the other two; I mean the trusting of the performance of the experiments to his servant, who, either from ignorance of the subject, or from carelessness, blunders two-thirds of them. This is more particularly striking, from the circumstance that many of his pupils come straight from Dr Hope's, where the experiments are performed in the neatest possible manner. Another bad consequence is, that the experiments very frequently give the Professor the lie, as the event is frequently the opposite of what he had asserted it would be. Thus, he one day stated, that wood, when closely compressed, would sink in water. The servant put a piece in a vice, gave it the required pressure, and threw it into water - when, lo! it swam..$^{53}$

What sort of general historical conclusions can be drawn from this small selection of humorous student magazines? It would be superfluous perhaps in the current context to attempt any specific comments on the nature of the wit itself, so much a part of institutional life. The social functions and philosophical aspects of humour have long been the subject of attention, from the writings of Freud and Henri Bergson to recent work by Michael Mulkay and 


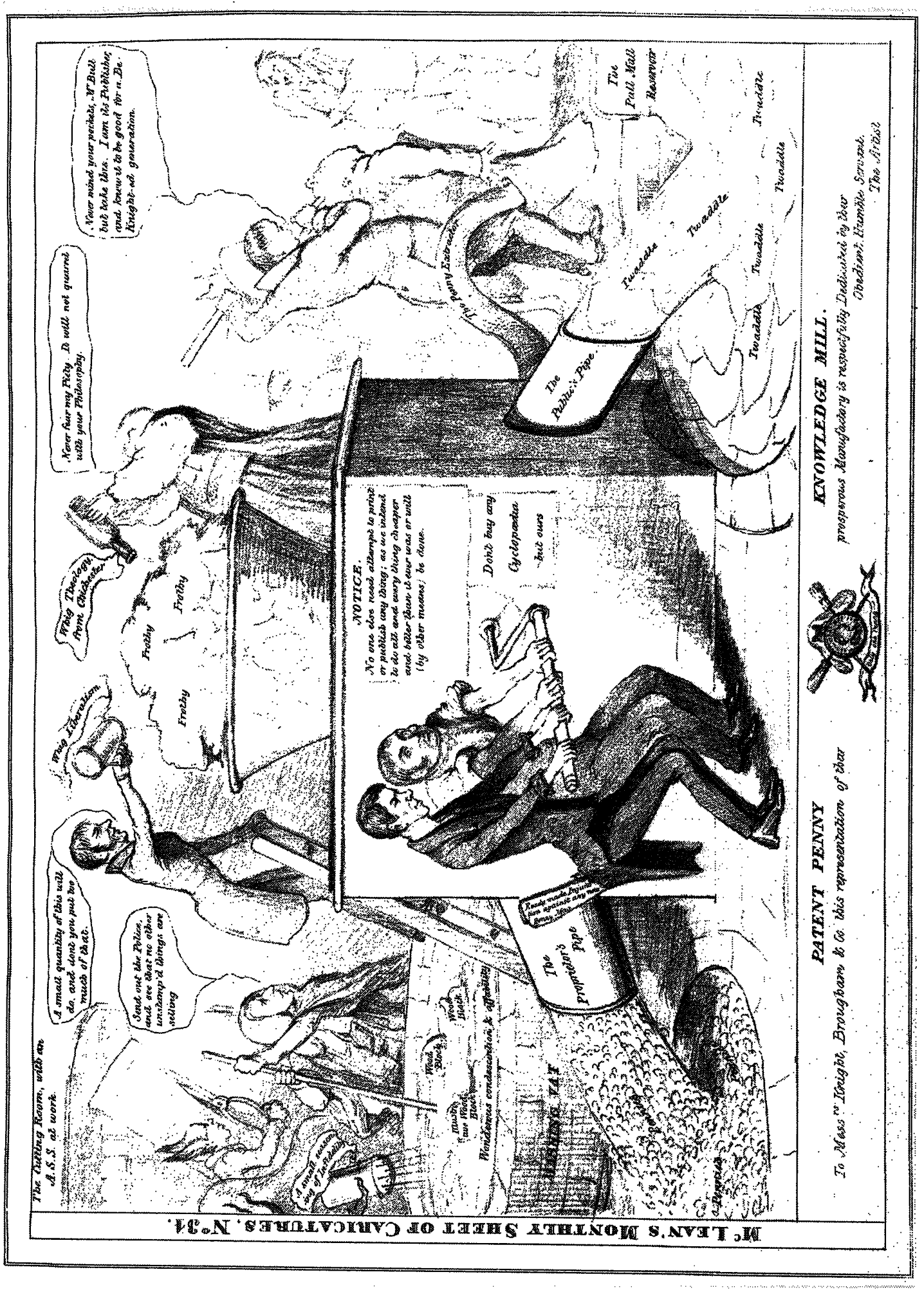

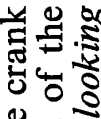

छे

을

ह

的

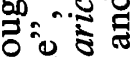

哂

뭉.

क्षै

동

$一$ 政

政

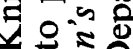
औ. हू

검

舫

융

作

$\infty$

그를

잉

흉형

更

可.

解

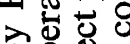

글



글

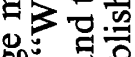

复

牙

30

남ㅇ

两

政

응윰웜

응

2.0.길

和管

$\dot{\nabla}$

$\stackrel{9}{9}$ 
the authors of a collection of essays edited by John Durant and Jonathan Miller; ${ }^{54}$ and comedy among particular social groupings and settings is actively studied, although most compilers of anthologies flinch from any deeper analysis of the interplay between cohesive and divisive factors that are patently involved. A trawl through any bookshop today reveals collections relating to medical humour, clerical humour, tombstone and deathbed humour, class humour ("not in front of the servants"), science fiction humour, humour in physics, and "ghosts with a touch of humour", not to mention perennials like Irish and Scottish jokes. Student satire is obviously a minor variant of this larger theme.

Humour in past student journals, however, is interesting in the way it merges, on the one hand, with the tradition of verses and literary fiction about university life, and, on the other hand, with the long-established custom of addressing public letters, broadsheets and ballads to prominent individuals. The first student journals can, in this sense, be seen as an extension of Swiftean pamphleteering, the tamer, more subdued verbal equivalents of political cartoons, although for the most part they look inwards at institutional and personal affairs than out to the world at large. It would add materially to our understanding of the world of higher learning if such student burlesques were as fully integrated into social studies of science as satire - especially satirical caricature - is with civil and cultural histories, or indeed with literary studies. ${ }^{55}$ Though science cannot field a Gillray or Cruickshank, somewhere in the background it must have its snarling muses.

Yet student journals did not replace or drive out the publication of controversial pamphlets any more than they stemmed the tide of serious literature about universities or undergraduate days: broadsheets, handbills, public letters, and mock-heroic odes and diatribes were still being issued sideby-side with undergraduate magazines at Cambridge and Oxford right through the nineteenth century; ${ }^{56}$ and Tennyson and Arnold hardly gave these transient journals a second thought when setting out on the road to publishing poems - even poems about their own university experiences - and opted for outlets that were much more respectable and widely distributed. Political or literary aims were, in these cases, best furthered by the traditional forms of publication that had emerged over the years. No student magazine ever made a poet laureate or toppled a chancellor.

The journals appear to represent a slightly different function, in that they are closely tied to a particular group of individuals in a particular institutional and social frame at a particular stage in their lives. It is not surprising, then, that the efflorescence of student magazines around 1825-35 coincided with the rise of the popular press and an extraordinary proliferation of periodicals catering for amorphous but identifiable groups among the reading public. Student journals comprised only a small sector in the vast sweep of titles that 
came into being during the first half of the nineteenth century, a sweep ranging from the well-known literary and foreign reviews, the quarterlies, annuals, weeklies and fortnightlies that included the Athenaeum, Saturday review, Chambers's Edinburgh journal and Charles Knight's influential Penny magazine, to the new range of newspapers pandering to every shade of political opinion, the professional, trade and household journals, the special-interest magazines (especially among the natural history sciences), the cheap religious tracts, the self-help and self-educative journals, the Chartist and radical reformist literature, phrenological, fashion, sporting, agricultural and gardening weeklies, and the serialized stories by which Dickens, Trollope and Thackeray came to their public, in addition to the transactions and proceedings of learned societies and literary institutions, themselves also becoming established in Britain in unprecedented numbers. ${ }^{57}$ According to Richard Altick, a subscriber to (the real) W. H. Smith's reading room in the Strand, London could find up to 150 different newspapers and magazines a week in $1825 .{ }^{58}$ As is well known, despite the rapid development of the radical press during the 1820s and beyond, the vast majority of these periodicals served the emergent middle, artisan and professional classes. Some, like the aptly named Student (f. 1846), were directed towards self-education at a relatively humble level, possibly the kind of magazine that might have been found in a Mechanics' Institute; others were clearly aimed at what could be called the Literary and Philosophical Society end of the market. Knight's famous dictum that knowledge ought to be the "common possession of every class of mankind" fuelled not only the prodigious publishing activities of the Society for the Diffusion of Useful Knowledge but spread cheap literature far and wide. Robert Seymour, the caricaturist, barely exaggerated when he drew Knight's machinery pumping out ceaseless magazines from the bags - and bags - of knowledge tipped in at the top (see Figure 4).

In the same way as the founders and publishers of each one of these miscellaneous journals identified and pushed their wares towards specific sectors of British society, the promulgators of student magazines seem to have similarly provided material for a recognisable audience: an audience of mostly well-to-do young men who held every expectation of joining the country's professional classes; an audience, moreover, that was becoming more selfaware of its own distinguishing character decade by decade. Academic reform - and the agitation for academic reform - must have been a powerful factor in encouraging such self-awareness. Social divisions between town and gown also notoriously excited party feeling. But it is not often remarked upon by university historians how greatly the numbers of undergraduates increased during the first third of the nineteenth century. A study by R. B. McDowell and David Webb of the annual intake at Trinity College Dublin is in this regard interesting, for it shows that the number of matriculations there rose 
rapidly from a figure of 103 in 1800 to 496 in 1826, and for the next two decades fluctuated at around 400 until 1844. Cambridge too saw a tripling of its intake over the same period..$^{59}$ Whereas only 213 students joined Edinburgh University in the years 1804 to 1810 , more than 700 entered over the following ten-year period. ${ }^{60}$ Recent research indicates that the number of medical matriculations might have been closer to 900 during the period 1813-33. ${ }^{81}$ Increased numbers of undergraduates in classes, in college halls, libraries, and out and about on the city streets, the not-so-funny jokes about town and gown on which The snob relied, the antagonism expressed by Edinbugh medical students towards their professors, the fights between students and locals most famously the "Snowball riots" of 1837-38 in Edinburgh when the militia was called out to separate the brawl (see Figure 2), but sufficiently regular features of life in Oxford and Cambridge to require internal policing and the appointment of university proctors to patrol the night-time streets - perhaps even the proliferation of self-electing student clubs, debating societies, dininggroups, and the major and minor associations, from the Apostles to Charles Darwin's "Glutton Club", would have all encouraged undergraduates to think of themselves as a discrete grouping whose views were important - at least to themselves.

Student magazines, under this view, may have been more than just joie de vivre transformed into print, although the pursuit of uncomplicated amusement should not be pushed too far into the background. Rather, they can additionally represent the consolidation of the idea of being a college 'man', in which science had its part as much as any other undergraduate occupation. Humour - especially the scientific humour put forward here - was undoubtedly an important element in creating a common matrix: the social cement, as it were, of the undergraduate world. Even the briefest announcement in one of these magazines is redolent with shared assumptions, convictions, and academic exasperations:

Wanted at Trinity Butteries, a strong healthy man who can undertake mathematically to divide a 7 shillings plum pudding into 150 sizings, as the present cutter only manages to get 149.

\section{ACKNOWLEDGEMENTS}

I would like to thank Joy Harvey, Stephen Jacyna, Michael Neve, Ian Patterson and Hugh Torrens for their help with this paper.

\section{REFERENCES}

1. The gownsman, 19 November 1829, 23.

2. Roger Cooter, The cultural meaning of popular science: Phrenology and the organization of 
consent in nineteenth-century Britain (Cambridge, 1984); Adrian Desmond, The politics of evolution: Morphology, medicine and reform in radical London (Chicago, 1989); Roy Porter (ed.), Patients and practitioners: Lay perceptions of medicine in pre-industrial society (Cambridge, 1985); Ann B. Shteir, "Botany in the breakfast room: Women and early nineteenth-century British plant study", in Pnina Abir-Am and Dorinda Outram (eds), Uneasy careers and intimate lives: Women in science, 1789-1979 (New Brunswick, N. J., 1987), 31-43; and James A. Secord, "Newton in the nursery: Tom Telescope and the philosophy of tops and balls, 1761-1838", History of science, xxiii (1985), 127-51.

3. The gownman, 31 December 1829, 66 .

4. Martin J. S. Rudwick, "Caricature as a source for the history of science: De la Beche's antiLyellian sketches of 1831", Isis, lxvi (1975), 534-60.

5. J. T. D. Hall (ed.), The Tounis College: An anthology of Edinburgh University student journals, 1823-1923 (Edinburgh, 1985).

6. Graham Chainey, A literary history of Cambridge (Cambridge, 1985). See also Charles Whibley (ed.), In cap and gown: Three centuries of Cambridge wit (London, 1889), and Harry C. Marillier, University magazines and their makers (London, 1902).

7. A complete listing of magazines published at Oxford and Cambridge universities is given in Marillier, University magazines (ref. 6), 71-93.

8. Standard sources for the expansion of the book and periodical trade and the development of a mass reading market are Richard Altick, The English common reader: A social history of the mass reading public, 1800-1900 (Chicago, 1957); Alvar Ellegaird, The readership of the periodical press in mid-Victorian Britain (Acta Universitatis Gothobergensis, 63, no. 3; Goteberg, 1957); and Joanne Shattock and Michael Wolff (eds), The Victorian periodical press: Samplings and soundings (Leicester, 1982). Further useful sources are A. A. Manton, "Development of European scientific journal publishing before 1850", in A. J. Meadows (ed.), Development of scientific publishing in Europe (Amsterdam, 1980), 1-22; David A. Kronick, A history of scientific and technological periodicals: The origins and development of the scientific and technological press, 1665-1790 (Metuchen, N. J., 1976); Walter Graham, English literary periodicals (London, 1930); and Richmond P. Bond (ed.), Studies in the early English periodical (Chapel Hill, N. C., 1957). See also, however, Desmond Flower, A century of best sellers, 1830-1930 (London, 1934); Amy Cruse, The Englishman and his books in the early nineteenth century (London, 1935); Robert Webb, The British working-class reader, 1790-1838: Literary and social tension (London, 1955); James J. Barnes, Free trade in books: A study of the London book trade since 1800 (Oxford, 1964); John Gross, The rise and fall of the man of letters: Aspects of English literary life since 1800 (London, 1969); Elizabeth L. Eisenstein, The printing press as an agent of change (Cambridge, 1979); Marjorie Plant, The English book trade: An economic history of the making and sale of books, 3rd edn (London, 1974); Nigel Cross, The common writer: Life in nineteenth century Grub Street (Cambridge, 1985); Jon P. Klancher, The making of English reading audiences, 1790-1832 (Madison, 1987); and John Feather, A history of British publishing (London, 1988).

9. New lapsus linguae, 24 January 1825.

10. University maga, 19 March 1835, 3.

11. E. Howe, "From Bewick to half tone: A survey of illustration processes during the nineteenth century", Typography, iii (1937), 19-23; Geoffrey Wakeman, Victorian book illustration: The technical revolution (Newton Abbot, 1973); and John Harthan, The history of the illustrated book: The Western tradition (London, 1981).

12. Hall, The Tounis College (ref. 5), 28-31, 42. The first case involved John Leslie, professor of natural philosophy, whose avarice was attacked in the Lapsus linguae in 1824. Leslie had already taken the editor of Blackwood's magazine successfully to court. For further

\section{Provided by the NASA Astrophysics Data System}


discussion of Leslie's "care of his fortune", see J. B. Morrell, "Science and Scottish reform: Edinburgh in 1826", The British journal for the history of science, vi (1972), 3856 . The question of anonymity is considered by $\mathrm{O}$. Maurer, "Anonymity versus signature in Victorian reviewing", University of Texas studies in English, xxvii (1948), 1-27, and M. R. Hillier, "The identification of authors: The great Victorian enigma" in J. D. Vann and R. T. Van Arsdel (eds), Victorian periodicals: A guide to research (New York, 1978), 12348. See also James R. Secord, "Behind the veil: Robert Chambers and Vestiges" in James R. Moore (ed.), History, humanity and evolution: Essays for John C. Greene (Cambridge, 1989), 165-94.

13. Josiah G. Smyly, Contributors to "Hermathena", 1873-1943 (Dublin, 1944).

14. Of the many studies relating to small-scale jobbing publishers, see particularly James Grant, The newspaper press (London, 1871), and Philip Brown, London publishers and printers (London, 1982). A full bibliography of sources is given by Lionel Madden and Diana Dixon, "The nineteenth century periodical press in Britain: A bibliography of modern studies", Toronto Victorian periodicals newsletter, 1975. See also, Robin Myers and Michael Harris (eds), Author/publisher relations during the eighteenth and nineteenth centuries (Oxford, 1983).

15. Lapsus linguae, 17 March $1824,122$.

16. Francis Jacques Sypher (ed.), Undergraduate papers: An Oxford journal (1857-58). A facsimile reproduction with an introduction (Delmar, N.Y., 1974), p. iv.

17. Gerald C. Monsman, “'Old Mortality' at Oxford”, Studies in philology, lxvii (1970), 359-89.

18. Hall, The Tounis College (ref. 5), 35.

19. The history of the university natural history museum - the personal fiefdom of the professor of natural history, Robert Jameson - is described briefly in D. B. Hall, A short history of the University of Edinburgh, 1556-1889 (Edinburgh, 1967). See also Alexander Grant, The story of the University of Edinburgh during the first three hundred years (London, 1884), and Victor Eyles, "Robert Jameson and the Royal Scottish Museum", Discovery, April 1954, 155-62. Further accounts that touch on the museum are given by Morrell, "Science and Scottish university reform" (ref. 12); James Ritchie, "A double centenary: Two notable naturalists, Robert Jameson and Edward Forbes", Proceedings of the Royal Society of Edinburgh, Section B (Biology), lxvi (1956), 29-58; and James A. Secord, "The discovery of a vocation: Darwin's early geology", The British journal for the history of science, xxiv (1991), 133-57.

20. Lapsus linguae, 12 January 1824, 12.

21. Leslie's natural philosophy class for women, and a second class in chemistry run the following year by Thomas Charles Hope, are discussed by Morrell, "Science and Scottish reform" (ref. 12).

22. The Cheilead, December 1826, 118.

23. Cooter, Cultural meaning of popular science (ref. 2), 22-24.

24. University medical and quizzical journal, January 1834, 19-22. The article is attributed to Edward Forbes in an annotated copy in the British Library.

25. The academic, 5 January $1826,12$.

26. Ruth Richardson, Death, dissection and the destitute (London, 1987), and Owen Dudley Edwards, Burke and Hare (Edinburgh, 1981).

27. The Cheilead, January 1827, 168.

28. Whibley, Cap and gown (ref. 6), p. xix.

29. The variable fortune of the stethoscope in medicine is discussed by Stanley J. Reiser, Medicine and the reign of technology (Cambridge, 1978). See also Malcolm Nicolson, "The introduction of percussion and stethoscopy to early nineteenth-century Edinburgh", in W. F. Bynum and Roy Porter (eds), Medicine and the five senses (Cambridge, forthcoming).

\section{Provided by the NASA Astrophysics Data System}


30. Lewis Melville, Thackeray: A biography (London, 1910), 54, also repeated in Ray's edition of the letters: see Gordon N. Ray (ed.), The letters and private papers of $W$. M. Thackeray (London, 1945), i, 79. Ray later corrected this mistake in Thackeray: The uses of adversity (1811-1846) (London, 1955), 457, n. 26.

31. An incident not discussed by D. A. Winstanley, Early Victorian Cambridge (Cambridge, 1940). See, however, John Willis Clark and Thomas McKenny Hughes (eds), The life and letters of the Reverend Adam Sedgwick (Cambridge, 1890), i, 335-7.

32. The British Library and Cambridge University Library both attribute The gownsman to Thackeray. In fact, an article by John P. Wright, "The Light blue: A Cambridge University magazine", Christ's College magazine, xxviii (1913), 7-13, describes a meeting with Williams (Wright's uncle) in which he confirmed his editorship of both journals.

33. "Science at Cambridge", Punch, 11 November 1848, 201.

34. Margaret Forster (ed.), William Makepeace Thackeray: Memoirs of a Victorian gentleman (London, 1978), 27.

35. The snob, 30 April 1829, 22.

36. Astley Williams, Notes and queries, 6th ser., $\mathrm{x}$ (1884), 419.

37. On that basis, Louis Melville reprinted Thackeray's fugitive pieces for The snob and The gownsman in idem (ed.), Stray papers by William Makepeace Thackeray: Being stories, reviews, verses and sketches (1821-1847) (London, 1901), 1-14.

38. Williams was at that time employed as Thackeray's mathematics tutor for the summer vacation and the two young men had gone to Paris, fondly believing their parents would think they were working; they took lodgings in a small English-run boarding-house recommended to them by Sedgwick ("a friend of Williams's") from which they sallied forth for dancing lessons and soirées and all the other non-mathematical pleasures catalogued in Thackeray's autobiography. In the same letter Thackeray stated that Sedgwick was staying at their pensione (see Ray, Letters and papers (ref. 30), i, 84-85). Sedgwick's own diary of the Continental tour he made that summer, however, seems to make the conjunction impossible. See Clark and Hughes, Life and letters of Sedgwick (ref. 31), i, 349-52.

39. The snob, 14 May 1829, 29-31.

40. The gownsman, 19 November $1829,17-20$. The journal is sometimes incorrectly catalogued as having been published in June to November 1830, an easy mistake due to the issue of an editorial preface dated June 1830 that is customarily bound at the front of a collected run of numbers, when it was in fact an afterword, bringing the series to a close. The issues themselves do not carry the year.

41. James A. Secord, Controversy in Victorian geology: The Cambrian-Silurian debate (Princeton, 1986), and Colin Speakman, Adam Sedgwick: Geologist and dalesman, 1785-1873 (London and Cambridge, 1982).

42. Clark and Hughes, Life and letters of Sedgwick (ref. 31), i, 285, 290, 357. Sedgwick's memoirs (only very sketchy) are in Cambridge University Library Archives, Add 7652. III, H2.

43. Simon Schaffer and Menachem Fisch (eds), William Whewell: A composite portrait (Oxford, 1991). Rachel Laudan, From mineralogy to geology: The foundations of a science, 1650 1830 (Chicago, 1987). Whewell's mineralogy is given some attention in a paper by John G. Burke, "Mineral classification in the early nineteenth century", in Cecil J. Schneer (ed.), Toward a history of geology (Cambridge, Mass., 1969), 62-77.

44. William Whewell, An essay on mineralogical classification and nomenclature (Cambridge, 1828).

45. William Whewell, "A general method of calculating the angles made by any planes of crystals, and the laws according to which they are formed", Philosophical transactions of the Royal Society of London, cxv (1825), 87-130.

\section{Provided by the NASA Astrophysics Data System}


46. Clark and Hughes, Life and letters of Sedgwick (ref. 31), i, 515.

47. Sedgwick's syllabus for his geology course was published in 1821. An extensively revised edition was issued in 1831 .

48. Jameson's syllabus for 1827 or thereabouts is in the Edinburgh University Archives, X 623/20, as are several incomplete sets of student notes. One of these, with a further set in the Wellcome Institute for the History of Medicine Archives, MS 3358, indicate that at least some of the advertised topics, particularly the invertebrates and the "philosophy of zoology" including the "origin of species", were not delivered. See also James A. Secord, "Edinburgh Lamarckians: Robert Jameson and Robert E. Grant", Journal of the history of biology, xxiv (1991), 1-18, p. 17.

49. Nora Barlow (ed.), The autobiography of Charles Darwin, 1809-1882 (London, 1958), 59-60, and the recollections of John Maurice Herbert, Darwin Archive, University Library Cambridge, DAR 112 (ser. 2), 67.

50. Lapsus linguae, 28 November 1825, 21-23.

51. Anti-Nemo, 30 November $1832,3$.

52. University maga, 29 January $1835,5-6$.

53. New lapsus linguae, 10 January $1825,49-50$.

54. Michael Mulkay, On humour: Its nature and its place in modern society (Cambridge, 1988). John Durant and Jonathan Miller (eds), Laughing matters: A serious look at humour (Harlow, 1988).

55. A useful, though elderly, study is given by Thomas Wright, $A$ history of caricature (London, 1865). See Vincent Carretta, The snarling muse: Verbal and visual political satire from Pope to Churchill (Philadelphia, 1983); Harry Thomas Dickinson, Caricatures and the constitution, 1760-1832 (Cambridge, 1986); Michael Duffy (ed.), The English satirical print, 1600-1832 (Cambridge, 1986); Edward Galligan, The comic vision in literature (Athens, Georgia, 1984); Simon Houfe, John Leech and the Victorian scene (Woodbridge, Suffolk, 1984); John Millar, Religion in the popular prints, 1600-1832 (Cambridge, 1986); and Mark Storey, Poetry and humour from Cowper to Clough (London, 1979).

56. Many of these separate publications are reprinted in Whibley, Cap and gown (ref. 6). For Oxford, see The Oxford spectator, 1867.

57. Shattock and Wolff, The Victorian periodical press (ref. 8). In addition to the works cited in ref. 8, see Henry Curwen, $A$ history of booksellers, the old and the new (London, 1873); Louis James, Fiction for the working man, 1830-1850 (Oxford, 1963); V. E. Neuberg, Popular literature (Harmondsworth, 1977); Susan Sheets-Pyenson, "From the north to Red Lion Court: The creation and early years of the Annals of natural history", Archives of natural history, $\mathrm{x}$ (1981), 221-49; and Robert M. Young, "Natural theology, Victorian periodicals, and the fragmentation of a common context", in idem, Darwin's metaphor: Nature's place in Victorian culture (Cambridge, 1985), 126-63.

58. Altick, The English common reader (ref. 8), 323.

59. R. B. McDowell and David Webb, Trinity College Dublin, 1592-1952: An academic history (Cambridge, 1982), 499-508.

60. Evidence, oral and documentary, taken and received by the Commissioners for visiting the Universities of Scotland, Parliamentary papers, xxxv (1837), Appendix, 128-9.

61. Alexander Morgan, "Matriculations in the Faculty of Medicine prior to 1858", University of Edinburgh journal, viii (2) (1936-37), 124-5. 